\title{
Mapping and QTL analysis of the barley population Chebec $\times$ Harrington
}

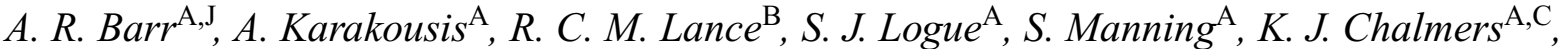 \\ J. M. Kretschmer ${ }^{\mathrm{A}}$, W. J. R. Boyd ${ }^{\mathrm{D}}$, H. M. Collins ${ }^{\mathrm{A}}$, S. Roumeliotis ${ }^{\mathrm{A}}$, S. J. Coventry ${ }^{\mathrm{A}}$,

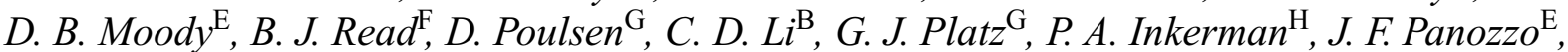 \\ B. R. Cullis, ${ }^{\mathrm{F}}$ A. B. Smith ${ }^{\mathrm{F}}$ P. Lim ${ }^{\mathrm{I}}$, and P. Langridge $\mathrm{A}$
}

\author{
${ }^{A}$ Department of Plant Science, University of Adelaide, Waite Campus, Glen Osmond, SA 5064, Australia. \\ ${ }^{B}$ Crop Improvement Institute, Department of Agriculture Western Australia, South Perth, WA 6151, Australia. \\ ${ }^{\mathrm{C}} \mathrm{CRC}$ for Molecular Plant Breeding, Glen Osmond, SA 5064, Australia. \\ DUniversity of Western Australia, Crawley, WA 6907, Australia. \\ ${ }^{\mathrm{E}}$ Department of Primary Industries, Horsham, Vic. 3400, Australia. \\ ${ }^{F}$ NSW Agriculture, Wagga Wagga Agricultural Institute, PMB Wagga Wagga, NSW 2650, Australia. \\ GHermitage Research Station, Queensland Department of Primary Industries, Warwick, Qld 4370, Australia. \\ ${ }^{\mathrm{H}}$ Lesley Research Institute, Queensland Department of Primary Industries, Toowoomba, Qld 4350, Australia. \\ ${ }^{\mathrm{I}}$ BiometricsSA, SARDI, Waite Campus, Glen Osmond, SA 5064, Australia. \\ ${ }^{\mathrm{J}}$ Corresponding author; email: andrew.barr@adelaide.edu.au
}

\begin{abstract}
A doubled haploid population of 120 individuals was produced from the parents Chebec, an Australian 2-row barley of feed quality with resistance to the cereal cyst nematode, and Harrington, a 2-rowed, Canadian variety of premium malting quality. This paper describes 18 field and laboratory experiments conducted with the population and summarises the traits mapped and analysed. The genomic location of 25 traits and genes is described and marker-trait associations for 5 traits (malt extract, diastatic power, resistance to cereal cyst nematode, early flowering, resistance to pre-harvest sprouting) important to Australian efforts to improve malting barley varieties have been used in practical breeding programs. Detailed maps for these populations are shown in this paper, while a consensus map incorporating these maps and further experiments on the populations are described elsewhere in this issue.
\end{abstract}

\section{Introduction}

The single most important issue facing breeders of malting barley in Australia is the improvement of malt extract. Australian breeders have targetted Canadian, Japanese, and European varieties as the most likely donors of genes to improve malt extract. Hence, Harrington was chosen as one potential donor of such genes. Harrington was bred by the University of Saskatchewan and released in 1981 (Harvey and Rossnagel 1984). Harrington has been a leading variety in Canada and neighbouring states of the USA since its release in 1981 until 2001. Its key features include spring growth habit, tall stature, wide adaptation, long basic vegetative period (bvp), high malt extract, low wort viscosity, and very high diastatic power (SD1 allele for $\beta$-amylase, Eglinton et al. 1998). The genetic control of key traits in Harrington has also been studied in the population Harrington $\times$ TR 306 by the North American Barley Genome Mapping Project (Tinker et al. 1996; Hayes et al. 1997; Mather et al. 1997).
The other parent is the Australian variety Chebec. Chebec was bred by D. H. B. Sparrow and R. C. M. Lance in South Australia and released in 1992. Chebec has some desirable features for malting, including moderate levels of malt extract, high free amino nitrogen, low wort viscosity, and low wort $\beta$-glucan, but it was not approved by the Australian malting industry because of its low diastatic power (SD2L allele for $\beta$-amylase, Eglinton et al. 1998) and low fermentability. Chebec has moderately tall straw, plump grain, short basic vegetative period, early maturity, adult plant resistance to net form net blotch, and resistance to the cereal cyst nematode (Heterodera avenae Woll.). Chebec was previously known as WI2737.

\section{Population construction}

Initially, the cross Chebec $\times$ Harrington was made at the Waite Campus in 1990. Doubled haploid plants were produced from $\mathrm{F}_{1}$ donors using the anther culture system. These were multiplied in 2-row by 4-m plots in 1993, to 
Table 1. Comparison of Chebec and Harrington for key traits when grown under South Australian conditions

\begin{tabular}{llll}
\hline Trait type & \multicolumn{1}{c}{ Phenotype } & \multicolumn{1}{c}{ Chebec } & Harrington \\
\hline Malt & Extract & Moderate & High \\
& Diastatic power & Low & Very high \\
& Viscosity & Low & Low \\
& $\beta$-amylase isoform & SD2L & SD1 \\
& Post harvest & Low & Very low \\
& dormancy & & \\
Disease & Cereal cyst nematode & Resistant & Susceptible \\
& Spot form net blotch & Moderate seedling resistance & Susceptible \\
Plant type & Stature & Moderately tall & Tall \\
& Spikelet & 2 row & 2 row \\
& Bvp & Short & Long \\
& Early growth & Erect & Erect \\
Grain size & Size & Moderately large & Moderately \\
& & (av. 48 mg) & small (av. 42mg) \\
\hline
\end{tabular}

provide seed for the South Australian and National Barley Molecular Marker Program (a nationally coordinated and funded program in Australia) field experiments in the period 1994-96.

One hundred and twenty individuals were chosen for map construction and phenotyping. Table 1 shows the comparison of Chebec and Harrington for key traits when grown under South Australian conditions.
Table 2. Markers used in construction of maps

\begin{tabular}{lc}
\hline Marker type & Numbers \\
\hline AFLP & 47 \\
RFLP & 258 \\
SSR & 41 \\
Other & 2 \\
Total & 348 \\
\hline
\end{tabular}

Table 3. Experiments conducted with the Chebec $\times$ Harrington population

\begin{tabular}{llllll}
\hline Type & Locations & State & Lat. & Long. & Aim of experiment \\
\hline & & & 1996 & & \\
Field & Strathalbyn & SA & 35 & 139 & Yield, grain, malt quality $^{\mathrm{A}}$ \\
Field & Pinery & SA & 34.5 & 138.5 & Yield, grain, malt quality $^{\mathrm{A}}$ \\
Field & Tarranyurk & Vic. & 36 & 142 & Yield, grain, malt quality $^{\mathrm{A}}$ \\
Field & Hermitage & Q1d & 28 & 152 & Yield $^{2}$ \\
Field & Kaimkillenbun & Qld & 27 & 151 & Yield, decimal growth stage \\
Field & Gairdner River & WA & 34 & 119 & Yield \\
Field & Wongan Hills & WA & 32 & 117 & Yield, decimal growth stage \\
Field & Wagga & NSW & 35 & 147 & Yield, decimal growth stage \\
Field & Blighty & NSW & 35.5 & 145 & Yield, decimal growth stage \\
& & & 1995 & & \\
Field & Balliang & Vic. & 38 & 144 & Yield \\
Field & Horsham & Vic. & 37 & 142 & Yield \\
Field & Kaimkillenbun & Qld & 27 & 151 & Yield \\
Field & Tipton & Qld & & & Yield \\
Field & Strathalbyn & SA & 34 & 139 & Yield \\
Field & Roseworthy & SA & 34.5 & 138.5 & Yield \\
Field & Wagga & NSW & 35 & 117 & Yield, decimal growth stage \\
Field & Wongan Hills & WA & 32 & 117 & Yield, decimal growth stage \\
& & & 2001 & & \\
Field & Esperance & WA & 34 & 122 & Black point, pre-harvest sprouting, \\
& & & & & grain colour \\
\hline
\end{tabular}

${ }^{\mathrm{A}}$ Grain and malt quality includes hardness, grain diameter, and grain weight (measured with SKCS system); grain protein; malt traits including soluble protein, wort $\beta$-glucan, Kolbach Index, free $\alpha$-amino nitrogen, diastatic power, IOB and EBC hot water extract and viscosity (J. F. Panozzo et al., unpublished data). 


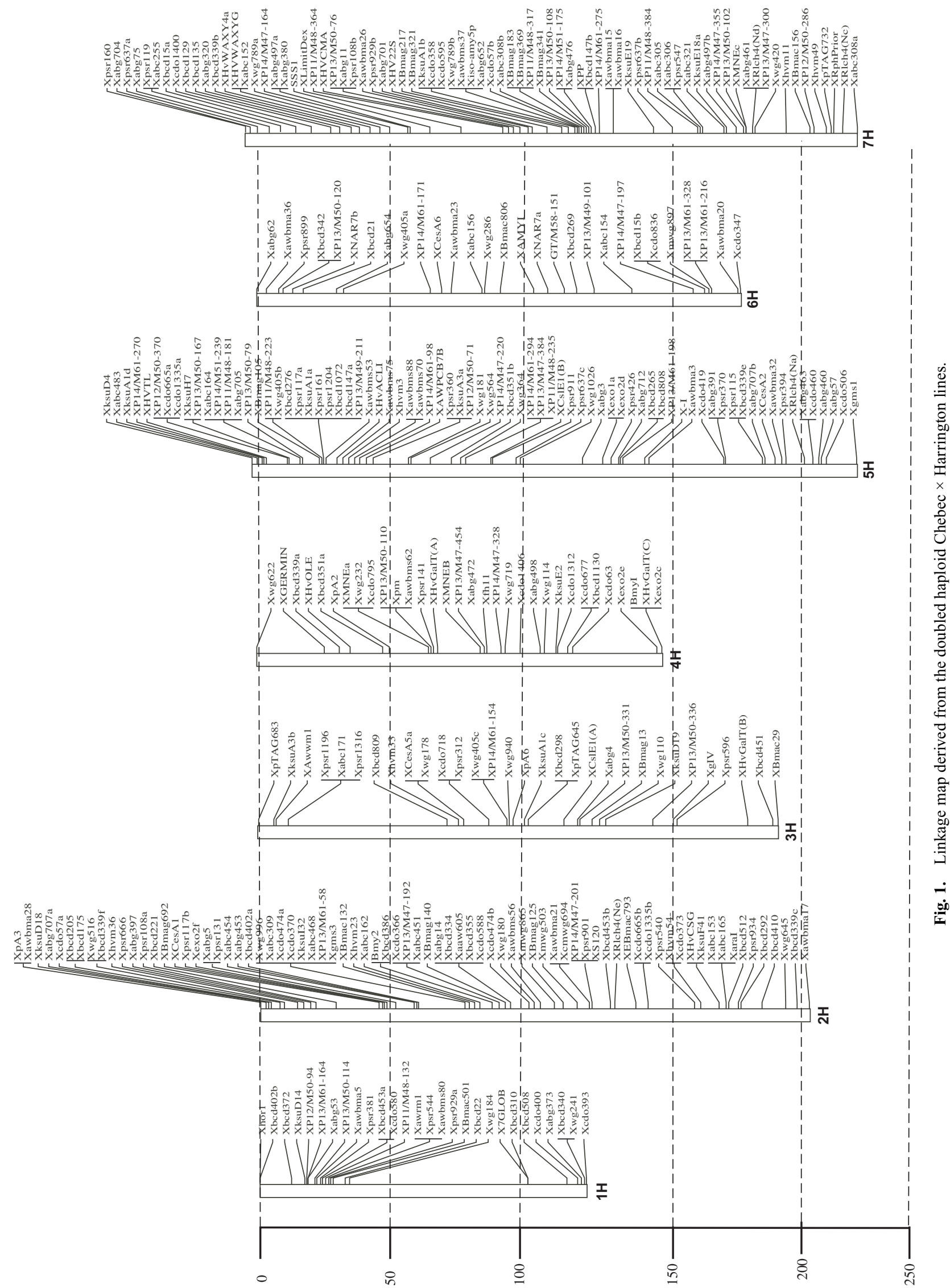


Table 4. Physiological traits and known gene markers mapped in Chebec $\times$ Harrington

\begin{tabular}{|c|c|c|c|}
\hline Trait & Locus & Chrom. & Reference \\
\hline \multicolumn{4}{|c|}{ Physiological } \\
\hline Cereal cyst nematode resistance & $\mathrm{Ha} 2$ & $2 \mathrm{H}$ & Kretschmer et al. (1997) \\
\hline Powdery mildew resistance & PM & $1 \mathrm{H}$ & B. Stephenson, pers. comm. (1998) \\
\hline Leaf rust resistance gene & Rph19 & $7 \mathrm{H}$ & Park and Karakousis (2002) \\
\hline \multicolumn{4}{|c|}{ Mapped genes } \\
\hline$\alpha$-L-arabinofuranosidase I (isoform I) & XAraI & $2 \mathrm{H}$ & Lee et al. (2001) \\
\hline Pollen specific gene family phalaris & XAWPPCB7B & $5 \mathrm{H}$ & Baumann (1995) \\
\hline Midgit clone from rye & Xawrm1 & $1 \mathrm{H}$ & Franki (1995) \\
\hline WM1 gene family & XAwwm1 & $3 \mathrm{H}$ & Whitford (2001) \\
\hline$\beta$-amylase & Xbmy (1-2) & $2 \mathrm{H}, 4 \mathrm{H}$ & Li et al. (1996); Li et al. (2002) \\
\hline Cellulose synthase $5-3^{\prime}$ fragment & $\mathrm{XCes} A(1,2,5 \mathrm{a}, 6)$ & $2 \mathrm{H}, 3 \mathrm{H}, 5 \mathrm{H}, 6 \mathrm{H}$ & $\begin{array}{l}\text { R. Burton and G. B. Fincher, } \\
\text { pers. comm. (2002) }\end{array}$ \\
\hline Cellulose synthase-like gene & $\mathrm{XCslE} 1(\mathrm{a}, \mathrm{b})$ & $3 \mathrm{H}, 5 \mathrm{H}$ & $\begin{array}{l}\text { R. Burton and G. B. Fincher, } \\
\text { pers. comm. (2002) }\end{array}$ \\
\hline$\beta$-glucan exo hydrolase isoenzyme exo 1 & XEXO1a & $5 \mathrm{H}$ & $\begin{array}{l}\text { A. Harvey and G. B. Fincher, } \\
\text { pers. comm. (1999) }\end{array}$ \\
\hline$\beta$-glucan exo hydrolase isoenzyme exo 2 & $\mathrm{XEXO} 2(\mathrm{c}, \mathrm{d}, \mathrm{e}, \mathrm{f})$ & $4 \mathrm{H}, 5 \mathrm{H}$ & $\begin{array}{l}\text { A. Harvey and G. B. Fincher, } \\
\text { pers. comm. (1999) }\end{array}$ \\
\hline Sucrose transporter & Xfh11 & $4 \mathrm{H}$ & $\begin{array}{l}\text { P. Whitfield, CSIRO, } \\
\text { pers. comm. }(2000)\end{array}$ \\
\hline$\beta$-Gluconase & XGIV & $3 \mathrm{H}$ & Li et al. (1996) \\
\hline Galactosyl transferase gene & XhvGalT(a,b,c) & $4 \mathrm{H}, 3 \mathrm{H}, 4 \mathrm{H}$ & $\begin{array}{l}\text { N. Farrokhi and G.B. Fincher, } \\
\text { pers. comm. }(2001)\end{array}$ \\
\hline Xylanase gene & X-I & $5 \mathrm{H}$ & Banik et al. (1997) \\
\hline Iso-amylase $5^{\prime}$ & Xiso-amyl5p & $7 \mathrm{H}$ & Burton et al. (2002) \\
\hline Limit dextrinase & XLD & $7 \mathrm{H}$ & $\operatorname{Li}(1997)$ \\
\hline Managanese efficiency & XMnea,b,c & $4 \mathrm{H}, 7 \mathrm{H}$ & Pallotta et al. (2000) \\
\hline $\begin{array}{l}\text { Ds flanking region fragment from transposon-tagged } \\
\text { population }\end{array}$ & $\mathrm{XpA}(2,3,6)$ & $4 \mathrm{H}, 2 \mathrm{H}, 3 \mathrm{H}$ & T. Koprek, pers. comm. (2001) \\
\hline Protein phosphortase & XPP & $7 \mathrm{H}$ & $\operatorname{Li}(1997)$ \\
\hline Disease resistance gene analogues & XRlch4N(a,c,d,e) & $5 \mathrm{H}, 7 \mathrm{H}, 7 \mathrm{H}, 2 \mathrm{H}$ & Seah et al. (1998) \\
\hline Resistance gene analogue, cDNA probe & XS120 & $2 \mathrm{H}$ & L. Madsen, pers. comm. (2000) \\
\hline cDNA for soluble starch synthase 1 & XSSS1 & $7 \mathrm{H}$ & S. J. Coventry, pers. comm. (2000) \\
\hline
\end{tabular}

Table 5. Key trait-marker associations implemented in Australian Breeding programs

\begin{tabular}{lllll}
\hline Trait & Locus & Chrom. & Positive allele & Reference \\
\hline Malt extract & Xabg57, XGMS01 & $5 \mathrm{H}$ & Harrington & Collins et al. (2003, this issue) \\
Diastatic power & Xabg57, XGMS01 & $5 \mathrm{H}$ & Harrington & Coventry et al. (2003a, this issue) \\
Cereal cyst nematode resistance & Aawbma21, Bmag125 & $2 \mathrm{H}$ & Chebec & Kretschmer et al. (1997) \\
Early flowering & Xabg2 & $2 \mathrm{HS}$ & Chebec & Coventry et al. (2003b, this issue) \\
& Xabg14, Xbmag140 & $2 \mathrm{HL}$ & Chebec & Coventry et al. (2003b) \\
Resistance to pre-harvest sprouting & Xabg57, XGMS01 & $5 \mathrm{H}$ & Chebec & Li et al. (2003, this issue) \\
\hline
\end{tabular}

\section{Construction of map}

Methods used for DNA extraction, type of markers assayed, linkage map construction, and quantitative trait loci (QTL) analysis are as described by Barr et al. (2003, this issue). Table 2 summarises the markers used to construct the map. The total genetic length of the map is $\sim 1330 \mathrm{cM}$. Distorted segregation ratios to the expected $1: 1$ were detected for specific chromosome segments located on $2 \mathrm{H}, 5 \mathrm{H}, 6 \mathrm{H}$, and $7 \mathrm{H}$. This observation has been previously documented by
Logue et al. (1995). Detailed maps of the 7 chromosomes are shown as Fig. 1.

\section{Phenotypic data collected}

Following seed multiplication in 1993, the full population was available for field experiments in 1994, 1995, and 1996 and 2001. Experiments were conducted at 16 locations spread over 5 states (Table 3). Two experiments were chosen from the 1995 and 1996 experiments on the basis of grain 
protein (preferably 9.5-12.0\%) and grain plumpness for malting.

In addition to the field trial program, Chebec $\times$ Harrington has been extensively used in mapping, genetic, and physiological studies (Table 4) which, when combined with the North American Barley Genome studies of Harrington $\times$ TR306 and Harrington $\times$ Morex (Tinker et al. 1996; Mather et al. 1997), make the Harrington genome a very well characterised model.

\section{QTL analysis}

MapManager QTX (Manly et al. 2001) was used to develop associations between markers and QTLs. Statistical associations were based on regression analysis. The likelihood ratio statistic (LRS) was calculated using the interval mapping functions in MapManager QTX. Permutation analyses (1000 iterations) were carried out to determine whether a particular value of the LRS was highly significant (99.9\%). The Q-gene analytical package (Nelson 1997) was used to confirm associations using interval mapping and maximum likelihood statistics [logarithm of odds ratio (LOD) values] and to generate graphical representations of maps and marker-trait associations.

The yield data from 15 experiments conducted in 5 states of Australia were analysed using spatial models. Yield and yield stability were associated with the basic vegetative period locus on $2 \mathrm{H}$ (B. R. Cullis and A. B. Smith, unpublished data). Additional detailed analyses of the malt quality data by Patrick Lim, Joe Panozzo, Monica Radcliffe, Belinda Evans, Brian Cullis, and Alison Smith have also been conducted.

\section{Validation}

Two major studies have been conducted to validate the effect of alleles identified from $\mathrm{Chebec} \times$ Harrington. They involve the Harrington alleles associated with diastatic power (Coventry et al. 2003a, this issue) and malt extract (Collins et al. 2003, this issue). These studies confirm that loci of crucial importance to breeding malting barley for Australian conditions were identified in this population.

A QTL for pre-harvest sprouting has been identified on chromosome $5 \mathrm{H}$ at the marker locus ABG57-GMS01, which explains over $70 \%$ variation for pre-harvest sprouting ( $\mathrm{Li}$ et al. 2003, this issue). This marker was validated in a Stirling $\times$ Harrington doubled haploid population.

\section{Implementation}

The most important traits identified in the Chebec $\times$ Harrington population are resistance to cereal cyst nematode (Kretschmer et al. 1997) and the QTL controlling malt extract and diastatic power, although other traits are also significant (Table 5).

\section{Conclusions}

The Chebec $\times$ Harrington population has been a valuable source of many genes, QTLs, and marker loci, 5 of which have been implemented in Australian breeding programs (Tables 4 and 5). These marker loci have been very valuable in Australian breeding programs as breeders attempt to transfer resistance to cereal cyst nematode from Chebec and the malt quality traits from Harrington into new malting barley lines. Through the work of Karakousis et al. (2003, this issue), several simple sequence repeat markers are now available for monitoring these traits in Australian breeding programs.

\section{References}

Banik M, Li CD, Langridge P, Fincher GB (1997) Structure, hormonal regulation and chromosomal location of gene encoding barley, 1,4$\beta$-xylan endohydrolases. Molecular and General Genetics 253, 599-608. doi:10.1007/S004380050362

Barr AR, Jefferies SP, Broughton S, Chalmers KJ, Kretschmer JM, Boyd WJR, Collins HM, Roumeliotis S, Logue SJ, Coventry SJ, Moody DB, Read BJ, Poulsen D, Lance RCM, Platz GJ, Park RF, Panozzo JF, Karakousis A, Lim P, Verbyla AP, Eckermann PJ (2003) Mapping and QTL analysis of the barley population Alexis $\times$ Sloop. Australian Journal of Agricultural Research 54, 1117-1123.

Baumann U (1995) Pollen mRNA of Phalaris coerulescens and their possible role in self-compatibility. PhD Thesis, Department of Plant Science, University of Adelaide.

Burton RA, Jenner H, Carrangis L, Fahy B, Fincher GB, Hylton C, Laurie DA, Parker M, Waite D, van Wegen S, Verhoeven T, Denyer K (2002) Starch granule initiation and growth are altered in barley mutants that lack isoamylase activity. The Plant Journal 31, 97-112. doi:10.1046/J.1365-313X.2002.01339.X

Collins HM, Panozzo JF, Logue SJ, Jefferies SP, Barr AR (2003) Mapping and validation of chromosome regions associated with high malt extract in barley (Hordeum vulgare L.). Australian Journal of Agricultural Research 54, 1223-1240.

Coventry SJ, Collins HM, Barr AR, Jefferies SP, Chalmers KJ, Logue SJ, Langridge P (2003a) Use of putative QTLs and structural genes in marker assisted selection for diastatic power in malting barley (Hordeum vulgare L.). Australian Journal of Agricultural Research 54, 1241-1250.

Coventry SJ, Barr AR, Eglinton JK, McDonald GK (2003b) The determinants and genome locations influencing grain weight and size in barley (Hordeum vulgare L.). Australian Journal of Agricultural Research 54, 1103-1115.

Eglinton JK, Langridge P, Evans DE (1998) Thermostability variation in alleles of barley $\beta$-amylase. Journal of Cereal Science 28, 301309.

Franki MG (1995) The Midget chromosome as a model to study cereal chromosome structure. PhD thesis, Department of Plant Science, University of Adelaide.

Harvey BL, Rossnagel BG (1984) Harrington barley. Canadian Journal of Plant Science 64, 193-194.

Hayes PJ, Cerono WHM, Kuiper M, Zabeau K, Sato A, Kleinhofs D, Kudrna A, Kilian M, Saghai-Maroof D, Hoffman and North American Barley Genome Mapping Project (1997) Characterizing and exploiting genetic diversity and quantitative traits in barley (Hordeum vulgare) using AFLP markers. Journal of Agricultural Genomics 2, http://www.ncgr.org/jag/

Karakousis A, Barr AR, Chalmers KJ, Ablett GA, Henry R, Langridge P (2003) Potential of SSR markers for plant breeding and variety 
identification in Australian barley germplasm. Australian Journal of Agricultural Research 54, 1197-1210.

Kretschmer JM, Chalmers KJ, Manning S, Karakousis A, Barr AR, Islam AKMR, Logue SJ, Choe YW, Barker SJ, Lance RCM, Langridge P (1997) RFLP mapping of the Ha 2 cereal cyst nematode resistance gene in barley. Theoretical and Applied Genetics 94, 1060-1064. doi:10.1007/S001220050515

Lee RC, Burton RA, Hrmova M, Fincher GB (2001) Barley arabinoxylan arabinofuranohydrolases: purification, characterization and determination of primary structures from cDNA clones. The Biochemical Journal 356, 181-189. doi:10.1042/0264-6021:3560181

Li CD (1997) Genetic control of hydrolytic enzymes in germinating barley (Hordeum vulgare L.). PhD thesis, Department of Plant Science, University of Adelaide, S. Aust.

Li CD, Langridge P, Lance RCM, Xu P, Fincher GB (1996) Seven members of the (1-3)-beta-glucanase gene family in barley (Hordeum vulgare) are clustered on the long arm of chromosome 3 (3HL). Theoretical and Applied Genetics 92, 791-796. doi:10.1007/S001220050194

Li CD, Langridge P, Zhang XQ, Eckstein PE, Rossnagel BG, Lance RCM, Lefol EB, Lu MY, Harvey BL, Scoles GJ (2002) Mapping of barley (Hordeum vulgare L.) beta-amylase alleles in which an amino acid substitution determines beta-amylase isoenzyme type and the level of free beta-amylase. Journal of Cereal Science 35, 39-50. doi:10.1006/JCRS.2001.0398

Li CD, Tarr A, Lance RCM, Harasymow S, Uhlmann J, Westcot S, Young KJ, Grime CR, Cakir M, Broughton S, Appels R (2003) A major QTL controlling seed dormancy and pre-harvest sprouting/ grain $\alpha$-amylase in two-rowed barley (Hordeum vulgare L.). Australian Journal of Agricultural Research 54, 1303-1313.

Logue SJ, Oti-Boateng C, Karakousis A, Kretschmer J, Manning S, Lance R, Langridge P (1995) Segregation analysis of DNA markers in anther culture-derived populations of barley (Hordium vulgare L.). In 'Proceedings of the 7th Australian Barley Technical Symposium'. Perth. pp. 210-217.
Mather DE, Tinker NA, Laberge DE, Edney M, Jones BL, Rossnagel BG, Legge WG, Briggs KG, Irvine RB, Falk DE, Kasha KJ (1997) Regions of the genome that affect grain and malt quality in a North American two-row barley cross. Crop Science 37, 544-554.

Nelson JC (1997) Q-gene: software for marker-based genomic analysis and breeding. Molecular Breeding 3, 239-245. doi:10.1023/ A:1009604312050

Pallotta MA, Graham GC, Langridge P, Sparrow DHB, Barker SJ (2000) RFLP mapping of manganese efficiency in barley. Theoretical and Applied Genetics 101, 1100-1108.

Park RF, Karakousis A (2002) Characterization and mapping of gene Rph19 conferring resistance to Puccinia hordei in the cultivar 'Reka 1 ' and several Australian barleys. Plant Breeding 121, 232-236.

Seah S, Sivasithamparam K, Karakousis A, Lagudah ES (1998) Cloning and characterisation of a family of disease resistance gene analogs from wheat and barley. Theoretical and Applied Genetics 97, 937-945.

Tinker NA, Mather DE, Blake TK, Briggs KG, Choo TM, Dahleen L, Dofing SM, Falk DE, Ferguson T, Franckowiak JD, Graf R, Hayes PM, Hoffman D, Irvine RB, Kleinhofs A, Legge W, Rossnagel BG, Saghai-Maroof MA, Scoles GJ, Shugar LP, Steffenson B, Ullrich S, Kasha KJ (1996) Loci that affect agronomic performance in tworow barley. Crop Science 36, 1053-1062.

Whitford R (2001) From intimate chromosome associations to wild sex in wheat (Triticum aestivum). PhD thesis, Department of Plant Science, University of Adelaide.

Manuscript received 15 November 2002, accepted 31 October 2003 